\title{
The Relationship between Iranian EFL Students' Achievement Goal Orientations and Their Gender
}

\author{
Nasser Rashidi", Fatema Javanmardi \\ Shiraz University
}

\begin{abstract}
Achievement goal orientation has been described as the set of purposes or reasons students may adopt for performing an academic task (Dweck, 1986; Pintrich, 2000). So, Goal orientation is one of the concepts that has emerged in educational psychology over the last few decades and also is one of the most important concepts regarding learning in any educational setting. Due to the importance of students' achievement goal orientation in the education context, and the influences that goals have on their learning processes and outcomes, in the present study, the researcher has tried to investigate the type of goal orientations held by Iranian EFL students and to examine if achievement goals are dependent on gender. To achieve the goal, achievement goal orientation questionnaires were distributed among 182 B.A. students, both males and females, majoring in English Literature at Shiraz University. Consequently, having analyzed the data, the researcher found that that mastery was the dominant type of goal orientation held by Iranian EFL students. Afterwards, performance approach, work avoidant, and performance avoidant goal orientations were respectively the achievement goal orientations held by them. Then, an independent sample t-test was run for the purpose of comparing the students both males and females with the type of achievement goal orientations held by them to see whether the achievement goal orientations are dependent on gender or not. Thus, the results indicated that there were no significant differences across gender groups. That is, the goal orientations held by the students were not dependent on gender.
\end{abstract}

Keywords Goal Orientation, Educational Psychology, Mastery Goal, Gender

\section{Introduction}

From among the different disciplines involved in language teaching such as sociology, linguistics, psychology, etc., one that has received a lot of attention over the past few decades is educational psychology. Educational psychology deals with how students learn in different educational settings. In fact, "since the 1960s the focus of research in second language acquisition has shifted from teaching to learning, and language learners have become the center of language teaching and learning" (Chun-huan, 2010, p.202). Accordingly, over the years, different psychological constructs such as the achievement motive construct, the achievement goal construct, and the like have been used in order to explain and predict the students' behavior in academic settings (Elliot, 2005). He believed that the focus of such constructs is on competence; and the study of competence and how students are motivated has had an important place in educational psychology. Elliot (2005) has also declared that "the construct that currently receives the most research attention in the literature on construct" (p.52).

* Corresponding author:

nrashidi@rose.shirazu.ac.ir (Nasser Rashidi)

Published online at http://journal.sapub.org/edu

Copyright (C) 2012 Scientific \& Academic Publishing. All Rights Reserved
In line with this statement, researchers and educators have examined different behaviors of students in order to make inferences about what motivates them. One of the inferences they have made about the students' motivation has been the goals they set. That is why recently, a new dimension to achievement motivation has been introduced by theorists called achievement goal theory (Rabideau, n.d). According to Pintrich and Schunk (2002), although different types of goal theories have been identified for achievement behavior, the main construct which is of great importance is goal orientation theory.

From the historical point of view, goal theory has been emerged from the current theoretical approaches to achievement motivation (McLellan, 2006). Moreover, it has been appeared as one of the most important approaches in order to understand the students' achievement motivation in the recent years (Midgley et al., 1998). According to Cocks and Watt (2004), the importance of this issue has been reflected "in revisions to the instruments used to assess students' goals" (p.82). Similarly, Deemer (2004) thought of achievement goal theory as "the predominant theory of motivation in the educational psychology literature" (p.13). In fact, literature has shown that goal orientation theory was proposed by Nicholls (1975) who believed that students adopt task involvement or ego involvement. However, from a general point of view, the achievement goal theory has been developed from the work of many famous researchers 
who were the main contributors to the goal orientation theory such as Ames (1992), Dweck (1986), and Nicholls (1984). Indeed, they established a new area of research in the academic motivational area.

More specifically, the emergence of achievement goal construct was in fact in the mid to late 1970s by independent or collaborative work of Ames, Dweck, Maehr, and Nicholls (Elliot, 2005). According to Elliot (2005), the emergence of Dweck's achievement goal conceptualization was from her study on grade-school-age children in achievement settings. Dweck (1986) and Dweck and Elliot (1983) tried to explain the reason of responding to failure on achievement tasks among the children with the same ability and concluded that they tended to adopt different goals in achievement settings. Furthermore, the emergence of Nicholls' achievement goal conceptualization was from his study on the conceptions of ability in children. In 1984, Nicholls mixed the findings of his study with the theories of adolescent and adult achievement motivation which leads to the emergence of achievement goal construct. The aim of achievement goal construct was to show or develop high ability or to avoid showing low ability. At that time, only two different goals were recognized in their studies; namely, learning goals and performance goals. They considered these two types of goals as opposite of each other on a single goal continuum. After that, Elliot (2005) stated that both Dweck and Nicholls in the mid to late 1980s started to conduct different empirical research in order to support their ideas regarding achievement goal constructs (e.g., Nicholls et al., 1985; Elliot \& Dweck, 1988). In the mid to late 1980s, other goal orientation theorists such as Dweck and Leggett (1988) conceptualized goals as reasons or purposes for engaging in some learning oriented activities. In 1988, Ames and Archer expanded the conceptions of the achievement goal construct which "could be applied at the classroom, as well as the individual, level of analysis" (Elliot, 2005, p.57). They investigated how different combinations of the two types of goals known before associated with different variables. Since that time, literature has identified multiple subcategories of goals in the goal orientation. Moreover, from the early 1990s until now, the number of research on achievement goal orientation both theoretically and empirically in different settings and for various majors has been increased.

DeShon and Gillespie (2005) believed that goal orientation is both the dominant approach in the study of achievement motivation recently and is one of the most motivational variables that have been studied frequently in applied psychology. They have declared that the construct of goal orientation has been developed in the educational psychology literature to examine and explain the students' differences in their learning processes in academic settings. Accordingly, in the past few decades, many researchers considered achievement goals as the chief theoretical proposals in the study of academic motivation (Elliot, 2005; Meece et al., 2006a). Similarly, Dweck and Elliot (1983) proposed that "achievement goals must lie at the heart of any analysis of achievement motivation" (p.653). Therefore, the study of students' goal orientations has emerged as a major framework for understanding students' achievement motivation in the educational settings (Midgley et al., 1998).

Accordingly, the researcher in the present study conceptualizes motivation through achievement goal orientation. According to Was (2006), "a prominent feature in motivation theory is the role of goals. Goals are defined as the end toward which effort is directed" (p.531). Goal orientation is one of the concepts that has emerged in educational psychology and also is one of the most important concepts regarding learning in any educational settings. Ames (1992) has considered goal orientation as an important motivational construct in organizational research that provides an explanation for the approaches, responses, and reasons that individuals use to engage in achievement activities.

It is worth mentioning that according to Brdar et al. (2006, p.54), "The type of academic goals pursued by students is one of the most important variables in motivational research in educational contexts." Indeed, the goals that students adopt will have an effect on their success and failure. Therefore, all goals are not directed towards approaching a desirable outcome; that is, good grades. They can also be directed towards avoiding an undesirable outcome; that is, being grounded for failure (Elliot, 2006). In fact, the reasons that students' motivation differs from each other, have to do with their goal orientations.

Furthermore, since students' characteristics are different from each other, different variables such as their gender may have an influence on the type of goal orientation they adopt and as a result on their academic achievement. Therefore, some researchers have suggested that gender might have important role in the achievement goal orientations that students adopt in different academic settings (Kenny-Benson et al., 2006). In a similar way, Eccles et al. (1993) have stated that since students' motivation differs from individual to individual, it is supposed that there should be difference between males and females with regards to the levels of motivation they have in different academic settings. However, literature has shown that little research examined the relationship between students' achievement goal orientations and their gender. In line with this statement, Byme (2011) has stated that

With much of the achievement goal research focusing on the educational outcomes for the different goal orientations, very few studies have been dedicated to examining the impact and/or differences of gender on the different achievement goals (p.28).

On the other hand, regarding gender differentiation and the adoption of different types of goal orientation, the few studies that have been done so far reported contradictory results which show that the types of goals that students adopt differ from each other regarding their gender in different academic settings and under various conditions (e.g., Meece \& Holt, 1993; Thorkildsen \& Nicholls; 1998; Pajares \& Valiante, 2001; Hinkley et al, 2001; Rijavec \& 
Brdar, 2002; Brdar et al., 2006; Kenney-Benson et al., 2006; Meece et al., 2006b; etc.).

As a final point, despite the fact that goal orientation plays a very important role in conceptualizing the motivation of students and predicting their academic achievement and also despite the relatively large number of studies done on issues related to achievement goal orientation, little research has been done particularly in the Iranian context to investigate the effect of gender on the types of achievement goal orientations held by students. Moreover, studies on the types of achievement goal orientations that students adopt have been failed to be considered specifically in Iran. So, the researcher has considered these issues as a research gap thus bridging this gap by the present research. Accordingly, in this study, the researcher has decided to explore the type of goal orientations held by Iranian EFL students and to examine whether achievement goals they adopt are dependent on gender or not.

\subsection{The purpose of the study}

It is supposed that students based on their own areas of interest follow different goals during their educational years which lead them toward doing different kinds of activities. However, some of them may not be aware of their own goals; therefore, they cannot be so much successful. Even if they know their goals, some of them do not know how to follow their goals in a right way in order to become successful. Consequently, when educators understand which types of goals students adopt most, they can both help them orient and develop their goals appropriately and they can have a better instruction or even encourage students to study better; therefore, they become more interested in learning and achieve higher scores. Moreover, they can help the unmotivated students to become motivated enough like other students and become successful in their academic settings.

Accordingly, the main objectives of this study are twofold: the first one is to explore the type of achievement goal orientations held by Iranian EFL students, and the second one is to examine if achievement goals that students adopt are dependent on gender.

\subsection{Research Questions}

In line with the above mentioned purposes, the following research questions were put forward:

1. What are the achievement goal orientations held by Iranian EFL students?

2. Are the achievement goal orientations dependent on gender? (Are there any significant differences across gender groups?)

\section{Method}

In this part, the method which was used in the present study is presented including a very brief explanation of the participants, the instruments, the data collection procedures, and the data analysis procedures. It is worth mentioning that this study is mostly a quantitative research since it deals with "statistical analysis of numeric data to understand and explain phenomena" (Ary et al., 2006, p.24).

\subsection{Participants}

The participants in the present study consisted of 182 B.A. students majoring in English Literature at Shiraz University. They were selected from all students at four years of education, who were accepted from the academic year of 1386 until the academic year of 1390 . The whole number of male students who participated in this study was 44 , whereas the number of female students was 138 .

\subsection{Instruments}

The only instrument used by the researcher in the present study was a questionnaire developed by Was (2006) designed to measure the four types of achievement goal orientations (i.e., mastery, performance approach, performance avoidant, and work avoidant) held by the students. This questionnaire consisted of 33 items based on a 6-point Likert Scale ranging from (1) very untrue; (2) mostly untrue; (3) somewhat untrue; (4) somewhat true; (5) mostly true or (6) very true measuring different goal orientations (See Appendix A). The reliability index of the questionnaire has already been estimated by Was (2006) using Cronbach's Alpha ranging from values of .64 to .81 . However, in order to determine the reliability of goal orientation scale in the present study, Cronbach alpha has been used once more for each subscale. Based on the results, the reliability coefficients for mastery, performance approach, performance avoidant and work avoidant goals were 0.85 , $0.71,0.74$, and 0.68 , respectively. Its construct validity has also been checked through confirmatory factor analysis using Amos 5 Software (Arbuckle, 2005) by Was (2006). Nevertheless, regarding the validity of goal orientation scale in the present study, the researcher just showed the questionnaire to the three of the professors at the department of foreign languages and linguistics at Shiraz University; and as a result, all of them confirmed such a questionnaire to be used in this study.

\section{Appendix A}

\section{Dear participant:}

The following questionnaire has been designed for a research project and all the information including even your name or student number will be confidential and will not be used anywhere when I write up the study. So, please tick the boxes below which best describes your characteristics.

Name/ Student No: Gender: Male Female

Year of education: Freshman Sophomore Junior Senior

Moreover, as mentioned before, each subscale was designed to measure different types of goals set by the students. For example, Was (2006) described each subscale as the following:

Mastery goal orientation: "Students with mastery goal 


\begin{tabular}{|c|c|c|c|c|c|c|}
\hline Items & $\begin{array}{c}\text { very } \\
\text { untrue }\end{array}$ & $\begin{array}{l}\text { mostly } \\
\text { untrue }\end{array}$ & $\begin{array}{c}\text { somewha } \\
\text { t untrue }\end{array}$ & $\begin{array}{l}\text { somew } \\
\text { hat true }\end{array}$ & $\begin{array}{c}\text { mostly } \\
\text { true }\end{array}$ & $\begin{array}{l}\text { very } \\
\text { true }\end{array}$ \\
\hline \multicolumn{7}{|l|}{ 1. I challenge myself with goals for a test based on my past exam results. } \\
\hline \multicolumn{7}{|l|}{$\begin{array}{l}\text { 2. I am more concerned with improving from week to week than I am in doing } \\
\text { better than others in the class. }\end{array}$} \\
\hline \multicolumn{7}{|l|}{$\begin{array}{l}\text { 3. Even when I am doing well in the class, I continue to work hard to improve } \\
\text { my understanding of the material. }\end{array}$} \\
\hline \multicolumn{7}{|l|}{$\begin{array}{l}\text { 4. In the class, I prefer material that arouses my curiosity, even if it is difficult } \\
\text { to learn. }\end{array}$} \\
\hline \multicolumn{7}{|l|}{ 5. I feel that the effort which leads to improvement increases my ability. } \\
\hline \multicolumn{7}{|l|}{ 6. My goal in the class is to do my best, even if others are doing better. } \\
\hline \multicolumn{7}{|l|}{ 7. I try to improve my test and assignment scores throughout the semester. } \\
\hline \multicolumn{7}{|l|}{ 8. I feel that I can increase my mental abilities through effort. } \\
\hline \multicolumn{7}{|l|}{$\begin{array}{l}\text { 9. I will try my best for every exam even if I know I do not need to try hard for } \\
\text { a good grade. }\end{array}$} \\
\hline \multicolumn{7}{|l|}{ 10. Doing well on an exam or assignment encourages me to do better. } \\
\hline \multicolumn{7}{|l|}{$\begin{array}{l}\text { 11. Understanding the content of the course is more important than just } \\
\text { getting a good grade. }\end{array}$} \\
\hline \multicolumn{7}{|l|}{ 12. In the class, I prefer material that challenges me. } \\
\hline \multicolumn{7}{|l|}{ 13. I am more concerned with doing my best than doing better than others. } \\
\hline \multicolumn{7}{|l|}{ 14. I believe that if I do not try hard in the class, but still do well, I am smart. } \\
\hline \multicolumn{7}{|l|}{ 15. It is important for me to do well in comparison to others in the class. } \\
\hline \multicolumn{7}{|l|}{ 16. I believe that intelligence is something you are born with. } \\
\hline Items & $\begin{array}{c}\text { very } \\
\text { untrue }\end{array}$ & $\begin{array}{l}\text { mostly } \\
\text { untrue }\end{array}$ & $\begin{array}{c}\text { somewha } \\
\text { t untrue }\end{array}$ & $\begin{array}{l}\text { somew } \\
\text { hat true }\end{array}$ & $\begin{array}{c}\text { mostly } \\
\text { true }\end{array}$ & $\begin{array}{l}\text { very } \\
\text { true }\end{array}$ \\
\hline \multicolumn{7}{|l|}{$\begin{array}{l}\text { 17. I want to do well in the class so that my friends, family, instructor, and } \\
\text { others can recognize my ability. }\end{array}$} \\
\hline \multicolumn{7}{|l|}{$\begin{array}{l}\text { 18. When exams or assignments are returned in the class, I immediately want } \\
\text { to compare my scores to others in the course. }\end{array}$} \\
\hline \multicolumn{7}{|l|}{ 19. I feel that if I try hard in the class, but do poorly, I am not very smart. } \\
\hline \multicolumn{7}{|l|}{ 20. My only goal for each course is to get the best grade in the class. } \\
\hline \multicolumn{7}{|l|}{$\begin{array}{l}\text { 21. I am more interested in doing better than the other students in the class, } \\
\text { than doing my best. }\end{array}$} \\
\hline \multicolumn{7}{|l|}{$\begin{array}{l}\text { 22. I am afraid that if I ask the instructor to help me, he or she may think that } \\
\qquad \text { I am not very smart. }\end{array}$} \\
\hline \multicolumn{7}{|l|}{$\begin{array}{l}\text { 23. When others ask me how I have done on tests or assignments in a course, } \\
\text { I often tell a lie and say I have done better than what I have actually done. }\end{array}$} \\
\hline \multicolumn{7}{|l|}{$\begin{array}{l}\text { 24. When tests or assignments are returned in a course, I do not want others to } \\
\text { know how I have done. }\end{array}$} \\
\hline \multicolumn{7}{|l|}{ 25. I often worry about doing poorly in the class. } \\
\hline \multicolumn{7}{|l|}{ 26. I worry more about getting a bad grade than understanding the material. } \\
\hline \multicolumn{7}{|l|}{ 27. I like my classes best, when there is not much to learn. } \\
\hline \multicolumn{7}{|l|}{$\begin{array}{l}\text { 28. I feel that having to try hard to do well in a class is the evidence of the lack } \\
\text { of ability. }\end{array}$} \\
\hline 29. I want to do as little work as I have to in the class. & & & & & & \\
\hline $\begin{array}{l}\text { 30. If I know I am getting an A in a class without much effort, I will not try } \\
\text { any more. }\end{array}$ & & & & & & \\
\hline $\begin{array}{l}\text { 31. Getting a good grade in the course is more important than understanding } \\
\text { the material covered. }\end{array}$ & & & & & & \\
\hline 32. I just want to do as much as I have to in order to do well in the class. & & & & & & \\
\hline 33. My primary goal in each course is to avoid getting a bad grade. & & & & & & \\
\hline
\end{tabular}

orientation focus on learning the material and mastering the tasks at hand. When oriented toward mastery or learning goals, students see achievement (success) as learning something new or mastering the task at hand" (p.531-532).

Performance approach goal orientation: "Students who are performance approach oriented view themselves as having a good deal of ability and wish to measure themselves against others performance hence, demonstrating their ability" (p.534).

Performance avoidant goal orientation: "Students with performance avoidance goal orientation view themselves as lacking ability and therefore wishing to avoid public demonstrations of achievement that would confirm their lack of ability" (p.534).

Work avoidant goal orientation: refers to the type of goals "in which failure is avoided without hard work and achievement is viewed as completing the task with as little effort as possible" (p.535).

\subsection{Data collection}

Since the main objectives of this study were to explore the type of goal orientations held by Iranian EFL students and to 
examine if achievement goals they adopt were dependent on gender or not, the achievement goal orientation questionnaires were distributed among all B.A. students in different years of education (i.e., freshmen, sophomores, juniors, and seniors) at Shiraz University. The allocated time to answer the questionnaires was 50 minutes. Moreover, the data pertaining to the other variable, that is, gender was gathered by the personal information that students provided in the questionnaires and they were also informed that all their information were confidential and used only for the present research project.

\subsection{Data Analysis}

The data gathered through the questionnaire on achievem ent goal orientation has been analyzed in the following way:

For the first research question, to describe the type of achievement goal orientations held by the students, the descriptive statistics of the data was employed. Regarding the achievement goal questionnaire, since the items under each subscale were not equal, the weighted mean of each subscale has been calculated in the way that the total scores of each subscale were divided by the number of the items of each subscale.

For the second research question, in order to compare males and females' scores on the four types of achievement goal orientations, a series of independent sample t-test were run.

\section{Results and Discussion}

As mentioned before, the fundamental purposes of this research were to determine the type of goal orientations held by Iranian EFL students and to examine if achievement goals they set were dependent on gender. Therefore, in this part, the findings of the study based on each research question have been presented respectively along with the relevant discussions. Moreover, the Tables have been presented in the Appendix B.

\section{Results and discussions of the types of achievement goal orientations held by Iranian EFL students}

The first question which was mentioned in this research was: What are the achievement goal orientations held by Iranian EFL students?

To answer this research question, the researcher made use of the descriptive statistical analysis of the data to describe the type of achievement goal orientations held by the students. Since the items under each subscale were not equal, the weighted mean of each goal has been calculated rather than the most common type of average (arithmetic mean). Thus, the total scores of each subscale were divided by the number of the items of each subscale. Accordingly, the result of the descriptive statistical analysis of the achievement goal orientations held by Iranian EFL students have been presented in Table 1 (See Appendix B).

The results of the Table 1 shows that among different types of goal orientations, the highest mean belonged to mastery goal orientation $(\mathrm{M}=4.42)$ and the lowest mean belonged to performance avoidant goal orientation $(\mathrm{M}=$ 2.58).

Therefore, as shown in Table 1, the results can be interpreted in this way that mastery $(M=4.42)$ was the dominant type of goal orientation held by the students. Afterwards, performance approach $(\mathrm{M}=3.51)$, work avoidant $(\mathrm{M}=3.20)$ and performance avoidant $(\mathrm{M}=2.58)$ goal orientations were respectively the achievement goal orientations held by Iranian EFL students.

\section{Appendix B}

Table 1. he result of descriptive statistical analysis of the achievement goal orientations held by Iranian EFL students

\begin{tabular}{|c|c|c|c|c|c|}
\hline & $\mathrm{N}$ & Minimum & Maximum & Mean & $\begin{array}{c}\text { Std. } \\
\text { Deviation }\end{array}$ \\
\hline mmastery & 182 & 2.23 & 6.00 & 4.42 & .74639 \\
\hline mpapproach & 182 & 1.00 & 5.88 & 3.51 & .79421 \\
\hline mpavoidant & 182 & 1.00 & 6.00 & 2.58 & .84741 \\
\hline mwavoidant & 182 & 1.00 & 6.00 & 3.20 & .92311 \\
\hline $\begin{array}{c}\text { Valid N } \\
\text { (listwise) }\end{array}$ & 182 & & & & \\
\hline
\end{tabular}

Table 2. The results of the independent sample t-test to compare both males and females in different types of achievement goal orientations

\begin{tabular}{|c|c|c|c|c|c|}
\hline Variables gender & Mean & $\mathrm{SD}$ & $\mathrm{t}$ & $\mathrm{df}$ & Sig. \\
\hline $\begin{array}{c}\text { Mastery male } \\
\text { female }\end{array}$ & $\begin{array}{l}56.04 \\
58.01 \\
\end{array}$ & $\begin{array}{l}9.52 \\
9.74 \\
\end{array}$ & 1.17 & 180 & N.S. \\
\hline $\begin{array}{c}\text { Papproach male } \\
\text { female }\end{array}$ & $\begin{array}{l}26.90 \\
28.52 \\
\end{array}$ & $\begin{array}{l}6.04 \\
6.41 \\
\end{array}$ & 1.47 & 180 & N.S. \\
\hline $\begin{array}{c}\text { Pavoidant male } \\
\text { female }\end{array}$ & $\begin{array}{l}17.38 \\
18.29 \\
\end{array}$ & $\begin{array}{l}5.72 \\
5.99 \\
\end{array}$ & .89 & 180 & N.S. \\
\hline $\begin{array}{c}\text { Wavoidant male } \\
\text { female }\end{array}$ & $\begin{array}{l}15.50 \\
16.18 \\
\end{array}$ & $\begin{array}{l}4.17 \\
4.74 \\
\end{array}$ & .86 & 180 & N.S. \\
\hline
\end{tabular}

It is worth mentioning that since students' amount of effort, behaviors and their use of strategies in a learning situation are guided by their goals for engagement in achievement settings (Dweck \& Leggett, 1988), different researchers in the field of educational psychology have investigated the relationship between different types of achievement goal orientations, various variables and academic achievement both directly and indirectly. However, none of them have examined only the type of achievement goal orientations held by the students directly except the study done by Kwok-wai et al. (2002) on the type of achievement goal orientations held by the preservice teachers in Hong Kong in which only two contrasting types of achievement goal orientations were known; namely, the learning goals and the performance goals. Accordingly, the finding of the present study is in contrast to what Kwok-wai et al. (2002) found; that is, in their studies the participants oriented more towards adopting performance goals than learning goals.

Consequently, since in this study the Iranian EFL students indicated more tendency to adopt mastery goals and less tendency to adopt performance avoidance goals, the researcher interpreted the results based on the definitions of such goals provided by various researchers. For example, according to Was (2006) "students with mastery goal 
orientation focus on learning the material and mastering the tasks at hand. When oriented toward mastery or learning goals, students see achievement (success) as learning something new or mastering the task at hand" (p.531-532). This shows that students with a mastery goal orientation are willing to improve new skills and as a result, develop their competence and their efforts are considered as a positive and effective way to achieve their goals (Kwok-wai et al., 2002). Whereas, "students with performance avoidance goal orientation view themselves as lacking ability and therefore wishing to avoid public demonstrations of achievement that would confirm their lack of ability" (Was, 2006, p.534). Thus, performance avoidant goal oriented students are concerned with not failing, and run from challenges or engage in self-sabotaging behaviors in order to have an excuse for their poor performance (Elliot \& McGregor, 2001).

Moreover, it can be suggested that the findings of the present study is of great importance since it is among the rare studies conducted so far regarding the type of achievement goal orientations held by the students especially in the context of Iran.

\section{Results and discussions of the effect of gender on the adoption of the students' achievement goal orientations}

The second question which was mentioned in this research was: Are the achievement goal orientations dependent on gender? (Are there any significant differences across gender groups?)

To answer this question, an independent sample t-test was run for the purpose of comparing the students both males and females with the type of achievement goal orientations held by them to see whether the achievement goal orientations are dependent on gender or not. Therefore, based on the results obtained from the table of Independent sample T-test (See Table 2 in Appendix B), there were no significant differences between males and females in all types of achievement goal orientations. That is, the achievement goal orientations were not dependent on gender. Mastery $(\mathrm{t}=1.17 \quad$ N.S. $)$, Performance approach ( $\mathrm{t}=1.47$ N.S.), Performance avoidant $(\mathrm{t}=.89$ N.S. $)$, and Work avoidant $(\mathrm{t}=.86 \quad$ N.S. $)$.

Consequently, the results of the present study can be supported by other researchers indicating that there were not any significant differences across gender groups of course, regarding the adoption of only some especial types of goals among the four types of goals that students adopt. For instance, in the study done by Pajares and Valiante (2001), no significant differences were found between males and females regarding only performance avoidance goals. Similarly, Hinkley, McInerney and Marsh (2001) and Kwok-wai et al. (2002) reported no significant differences across gender groups regarding their mastery goals. In the same way, other studies have identified no difference concerning performance goal orientation between males and females (e.g., Meece \& Holt, 1993; Niemivirta, 1996).

However, some studies demonstrated contradictory results with the present research regarding gender differentiation and the adoption of different types of goal orientation held by students. That is, these studies indicated that there was a significant relationship between gender and the type of achievement goal orientations held by students in different academic settings and of course under various conditions. For example, the results of the study done by Kenney-Benson and his colleagues (2006) showed that boys' and girls' approaches differed towards their academic tasks and that may be related to the type of goal orientations that they adopt. Girls were more concerned with learning goals than boys; whereas, boys were more intended to adopt ability or performance goals and to be viewed as smart to others. Similarly, other researchers more or less came to the same conclusion; that is, females were found to be more interested in adopting mastery goals more than males (e.g., Meece \& Holt, 1993; Pajares \& Valiante, 2001; Hinkley et al., 2001; Brdar et al., 2006; Meece et al., 2006b); whereas, males had more tendencies toward performance goals (e.g., Ryan et al., 1997; Middleton \& Midgley, 1997; Patrick et al., 1999). In contrast, the results of another study indicated that females were more performance goal oriented than males (e.g., Kwok-wai et al., 2002).

Additionally, the results of some other studies demonstrated that avoidance goals were more associated with males than females. For example, males were found to be more performance avoidant goal oriented than females (e.g., Hinkley et al., 2001; Brdar et al., 2006; Meece et al., 2006b). It is also interesting to note that other studies by Thorkildsen and Nicholls (1998), Rijavec and Brdar (2002), and Brdar et al. (2006) have shown that work avoidance goals were also more usual and related to males than females.

Although throughout the history of goal orientation theory literature has shown that little research examined the relationship between students' achievement goal orientations and their gender, some other empirical research regarding the same issue in conjunction with different variables indicated that female students showed more tendency toward performance goal orientation than males (e.g., Chan et al., 2004). On the contrary, males were more performance approach goal oriented than females (e.g., Byme, 2011; Middleton \& Midgley, 1997). Furthermore, in the study done by Tercanlioglu (2004), although no significant differences were found on the effect of gender on both task and ego orientations, female students had more tendency to adopt task orientation; whereas, male students tended to adopt more work avoidant goals than females. In the same way, Pajares et al. (2000) reported that females were more task goals oriented than males.

\section{Conclusions}

In educational psychology research, motivation is regarded as an internal state that students bring to a task along with the goals they held which leads to their success or failure. In fact, what is of great importance for the success of 
students in the education context is to understand the origin of students' motivation. "Based on literature and research findings, it is anticipated that achievement goal orientations would be prominent determinants of students' motivation and achievement behavior" (Kwok-wai et al., 2002, p.20). Accordingly, goal theorists have declared that motivation is supposed to be conceptualized as goal-directed behaviors that are shown by learners in an achievement environment (Ames, 1992). So, due to the importance of goal orientation in educational psychology over the past few decades regarding learning and individual differences in any educational settings and the influences that goals have on students' learning processes and outcomes, in the present study, the researcher has tried to investigate the type of goal orientations held by Iranian EFL students and to examine if achievement goals were dependent on gender. Consequently, the results of the first question of the study (i.e., what are the achievement goal orientations held by Iranian EFL students?) indicated that mastery was the dominant type of goal orientation held by the students. Afterwards, performance approach, work avoidant, and performance avoidant goal orientations were respectively the achievement goal orientations held by Iranian EFL students. In fact, whether students are learning goal oriented or performance goal oriented has been considered to be a function of individual differences (Dweck, 1986; Ames, 1992). Regarding the second research question (i.e., are the achievement goal orientations dependent on gender?), no significant differences were found between males and females in all types of achievement goal orientations. That is, the achievement goal orientations were not dependent on gender.

However, the findings of the present research make a useful and necessary contribution to the educational systems. That is they can provide clearer and more valuable information for both teachers and the students. For example, when teachers understand which types of goals students adopt most, they can both help them orient and develop their goals appropriately and they can have a better instruction or even encourage students to study better; therefore, the students even the unmotivated ones become more interested in learning and achieve higher scores.

Moreover, the most important limitation of this study was related to the disproportionate samples that were used in this study. That is, the number of males was fewer than the number of females. Nonetheless, future work should use more proportionate samples to see whether gender affects the type of goal orientation held by students or not.

Finally, the findings of the present study cannot be generalized to other contexts since in different contexts and under various conditions, the results might be different. So, the researcher suggested another replication of this study so that the importance of goal orientation studies specifically regarding the types of goals that students adopt increases.

\section{REFERENCES}

[1] Ames, C. (1992). Classrooms: Goals, structures, and student motivation. Journal of Educational Psychology, 84 (3), 261-271

[2] Ary, D., Jacobs, L. C., Razavieh, A., \& Sorensen, C. (2006). Introduction to research in education ( 7 th Ed). Thomson Wadsworth, Thomson Higher Education

[3] Brdar, I., Rijavec, M., \& Loncaric, D. (2006). Goal orientations, coping with school failure and school achievement. European Journal of Psychology of Education, $21(1), 53-70$

[4] Byme, S. R. (2011). Motivation: Goal orientation among middle school students. Thesis. College of Liberal Studies, Program Department of Psychology, School Psychology

[5] Chan, K. W., Leung, M. T., \& Lai, P. Y. (2004). Goal orientations, study strategies and achievement of Hong Kong teacher education student. Hong Kong Institute of Education. Paper presented at the AARE2004 Conference held at Melbourne, Australia, 28th Nov.-2nd Dec, 1-15

[6] Chun-huan, F. (2010). A correlational study of language learning motivation and strategies of Chinese undergraduate. Canadian Social Science, 6(4), 202-209

[7] Cocks, R. J. \& Watt, H. M. G. (2004). Relationships among perceived competence, intrinsic value and mastery goal orientation in English and Maths. The Australian Educational Researcher, 31(2), 81-112

[8] Deemer, S. A. (2004). Using achievement goal theory to translate psychological principles into practice in the secondary classroom. American Secondary Education, 32 (3), 4-15

[9] DeShon, R. P., \& Gillespie, J. Z. (2005). A motivated action theory account of goal orientation Journal of Applied Psychology, 90 (6), 1096-1127

[10] Dweck, C. S. (1986). Motivational processes affecting learning. American Psychologist, 41 (10), 1040-1048

[11] Dweck, C., \& Elliot, E. (1983). Achievement motivation. In E. Heatherington (Ed.), Handbook of child psychology (Vol. 4, pp. 643-691). New York: John Wiley

[12] Dweck, C. S. \& Leggett, E. L. (1988). A social-cognitive approach to motivation and personality. Psychological Review, 95 (2), 256-273

[13] Eccles, J. S., Wigfield, A., Harold, R. D., \& Blumenfeld, P. (1993). Age and gender differences in children's self- and task perceptions during elementary school. Child Development, $64,830-847$

[14] Elliot, A. J. (2005). A conceptual history of the achievement goal construct. In A. J. Elliot \& C. S. Dweck (Eds.), Handbook of competence and motivation (pp.52-72). New York: Guilford Press

[15] Elliot, A. (2006). The hierarchical model of approach-avoidance motivation. Motivation and Emotion, 30 (2), 111-116

[16] Elliott, E. S., \& Dweck, C. S. (1988). Goals: An approach to motivation and achievement. Journal of Personality and Social Psychology, 54, 5-12 
[17] Elliot, A. J., \& McGregor, H. A. (2001). A $2 \times 2$ achievement goal framework. Journal of Personality and Social Psychology, 80 (3), 501-519

[18] Hinkley, J. W., McInerney, D. M., \& Marsh, H. W. (2001). The multi- faceted structure of school achievement motivation: A case for social goals. Paper presented at the Annual Meeting of the American Educational Research Association, Seattle, USA

[19] Kenny-Benson, G. A., Pomerantz, E. M., Ryan, A. M., \& Patrick, H. (2006). Sex differences in math performance: The role of children's approach to schoolwork. Developmental Psychology, 42, 11-26

[20] Kwok-wai, CH., Po-yin, L., Man-tak, L. \& Phillip, M. (2002). Hong Kong preservice teachers' achievement goal orientations - are they related to their gender and electives? Hong Kong Teachers' Centre Journal, 1, 20-31

[21] McLellan, R. (2006). The impact of motivational "world-view" on engagement in a cognitive acceleration programme. International Journal of Science Education, 28 (7), 781-819

[22] Meece, J. L., Anderman, E. M., \& Anderman, L. H. (2006a). Classroom goal structure, student motivation and academic achievement. Annual Review of Psychology, 57, 487-503

[23] Meece, J. L., Glienke, B. B., \& Burg, S. (2006b). Gender and motivation. Journal of School Psychology, 44, 351-373

[24] Meece, J. L., \& Holt, K. (1993). A pattern analysis of students' achievement goals. Journal of Educationa1 Psychology. 85 (4), 582-590

[25] Middleton, M. J. \& Midgley, C. (1997). Avoiding the demonstration of lack of ability: An underexplored aspect of goal theory. Journal of Educational Psychology, 89(4), $710-718$

[26] Midgley, C., Kaplan, A., Middleton, M., Maehr, M. L., Urdan, T., Anderman, L. H., Anderman, E. \& Roeser, R. (1998). The development and validation of scales assessing students' achievement goal orientations. Contemporary Educational Psychology, 23, 113-131

[27] Nicholls, J. G. (1975). Causal attributions and other achievement-related cognitions: Effects of task outcome, attainment value, and sex. Journal of Personality and Social Psychology, 31, 379-389

[28] Nicholls, J. G. (1984). Achievement motivation: Conceptions of ability, subjective experience, task choice, and performance. Psychological Review, 91, 328-346
[29] Nicholls, J. G., Patashnick, M., \& Nolen, S. B. (1985). Adolescents' theories of education. Journal of Educational Psychology, 77(6), 683-692

[30] Niemivirta, M. (1996). Motivational-cognitive components in self-regulated learning. Paper presented at the 5th International Conference on Motivation, Landau, Germany

[31] Pajares, F., Britner, Sh. L., \& Valiante, G. (2000). Relation between achievement goals and self-beliefs of middle school students in writing and science. Contemporary Educational Psychology, 25(4), 406-422

[32] Pajares, F. \& Valiante, G. (2001). Gender differences in writing motivation and achievement of middle school students: A function of garner orientation? Contemporary Educational Psychology, 26, 366-381

[33] Patrick, H., Ryan, A. M., \& Pintrich, P. R. (1999). The differential impact of extrinsic and mastery goal orientations on males' and females' self-regulated learning. Learning and Individual Differences, 11, 153-171.

[34] Pintrich, P. (2000). An achievement goal theory perspective on issues in motivation terminology, theory, and research. Contemporary Educational Psychology, 25, 92-104.

[35] Pintrich, P. R., \& Schunk, D. H. (2002). Motivation in education: theory, research, and applications (2nd ed.). Upper Saddle River, New Jersey: Prentice-Hall.

[36] Rabideau, S. T. (n.d). Effects of achievement motivation on behavior. Rochester Institute of Technology, 1-13. Retrieved Dec. 18, 2010 from http://www.personalityresearch.org/pape rs/rabideau.html

[37] Rijavec M., \& Brdar I. (2002). Coping with school failure and self-regulated learning. European Journal of Psychology of Education, 17(2), 177-194.

[38] Ryan, A. M., Hicks, L., \& Midgley, C. (1997). Social goals, academic goals, and avoiding seeking help in the classroom. Journal of Early Adolescence, 17, 152-171.

[39] Tercanlioglu, L. (2004). Achievement goal theory: A perspective on foreign-language-learners' motivation. TESL Canada Journal, 21 (2), 34-49.

[40] Thorkildsen, T. A., \& Nicholls, J. G. (1998). Fifth-graders' achievement orientations and beliefs: Individual and classroom differences. Journal of Educational Psychology, 90, 179-201.

[41] Was, C. (2006). Academic achievement goal orientation: Taking another look. Electronic Journal of Research in Educational Psychology, 4(3), No.10, 529-550. 